\title{
Exploring the Ivorian Shea Butter Potentialities: Consumers and Scientists Approach
}

\author{
R.-M. Mégnanou and S. Niamké
}

\section{ABSTRACT}

Traditional shea butter is generally obtained through various uncontrolled methods, leading to a wide variability of quality. Nevertheless, consumers often complain about this fat because of it unconformity with their demands. Indeed, Ivorian ordinary consumers mostly prefer whitish odorless and fondant shea butter. Moreover, traders and industries interest in shea butter as raw material, would reside in its exceptional quality and potentialities of exploitation in several fields. An optimized traditional process was proposed by the present authors not only as a standard method, but also as a response to the whole users' exigencies. Resulting beige and yellow shea butters present very weak acid and peroxide indexes, very high unsaponifiable matters. Viscosity decreased exponentially with the temperature increasing, when UV-Vis and near infra-red spectra revealed presence of UV-filter compounds, carotenoids, and chlorophyll. Chromatographic profile identified palmitic, stearic, arachidic acids, and essential fatty acids like oleic and linoleic and also exaltolides compounds. Samples also contained essential minerals (Calcium, magnesium, zinc, iron, etc.) carotene, vitamins $A$ in relatively important amounts. Moreover, neither microbiological germs nor heavy were detected.

All these valorizing characteristics would confer to the optimized shea butters good aptitude for households feeding and body care, and also profile a wide range of exploitation in food, cosmetic and pharmaceutical industries.

Keywords: Shea butter, quality, optimization, feeding, potentiality, food industries.

\section{INTRODUCTION}

Shea butter tree (Vitellaria paradoxa, syn. Butyrospermum parkii, B. paradoxa), represents an important socioeconomical agro-resource for the producing countries [1], [2]. This importance is not only linked to the nuts and the butter commercialization, but mainly to the wide range of usages [3]. According to these authors, shea butter has long been used in sub-Saharan Africa and elsewhere for medicinal, culinary, and other applications. Nowadays, this oleaginous plant serves as a cocoa butter equivalent (CBE) in the manufacture of chocolate as well as ingredient in cosmetic and pharmaceutical industries [4]-[7]. About shea butter exploitation in these latest industries, it is worth noting that shea Butter has shown to be a valuable moisturizer, with exceptional healing properties for the skin. In fact, shea butter is involved in the treatment of skin allergies, insect bites, sunburns, frostbites, and a number of other conditions of the skin.

The increasing interest of industrials for traditional shea butter (known as bio-product) would potentially increase income, but at the same time induce many demands which
Published Online: April 29, 2021

ISSN: $2684-5199$

DOI: 10.24018 /ejbio.2021.2.2.180

\section{R.-M. Mégnanou}

Laboratoire de Biechnologies, UFR Biosciences, Université Félix Houphouet-Boigny, Abidjan, Côte d'Ivoire.

(e-mail: megnanour ${ }^{@}$ yahoo.fr)

S. Niamké*

Laboratoire de Biechnologies, UFR Biosciences, Université Félix Houphouet-Boigny, Abidjan, Côte d'Ivoire.

(e-mail: niamkes@yahoo.fr)

*Corresponding Author enhance competition for a better quality level. Indeed, more than the usual standards established by the Codex Alimentarius or any other organization, specific standards for shea butter have to be taken into account as function to the industrial sector [8]. Moreover, better would be the quality of shea butter samples and higher would be their international purchase price.

Whereas, in the whole producing countries, the shea butter factory depends mainly on the work of women and their own approach of process with factors (drying time, roasting time, etc.) that are generally uncontrolled. Indeed, a wide variety of shea butter with diverse colors, odors and textures are proposed in producing and non-producing areas to consumers who would make their choice as function to their acceptability or utilization purpose [9], [10]; but they often complain about the quality. The greatest part of produced shea butter is exploited by local industries or forwarded abroad [1], [11]. Nevertheless, industries also always complain about shea butter quality; this consequently affects the purchase prices which would decrease with the quality.

Several studies have been undertaken in Africa and abroad in order to improve shea butter quality; many of them underlined the effect of some manufacturing factors on its 
quality [3], [12], other drew the difference between shea butters from different countries [13] and between shea butter and other fats like cocoa butter [5]. In Côte d'Ivoire, Soro [14] and Nafan [15] established difference within trees of shea butter through ethno-botanical and genetic characterizations. However, though shea butter standards generally concern the physicochemical and microbiological qualities, it would be rather focusing on acceptability by consumers and potentialities of utilization. More specifically, characteristics of traditional shea butter sold on Ivorian markets might be known and consumers' criteria for shea butter choice might also be established. Then optima conditions for getting highly competitive shea butter might be defined. The present study intends to valorize the optimized traditional shea butter in order to obtain performed bio-shea butter with a wide potential of utilization. Hence, the sensorial characteristics of traditional shea butter sold on Ivorian markets were drawn up and confronted with consumers' criteria which were identified through a survey. Then, the physicochemical and microbiological of the same materials were determined and the potentialities of utilization were demonstrated. The effect of manufacturing factors was also evaluated and led to the identification of the optima conditions for defining the optimized traditional process. At the end of the study, the sensorial, physicochemical, nutritive, and microbiological characteristics of the optimized bio-shea butter were determined, and the potential uses were revealed.

\section{OVERVIEW ON THE SENSORIAL CHARACTERISTICS OF TRADITIONAL MARKETED SHEA BUTTERS}

\section{A. Ivorian Consumers' Approach about Shea Butter}

In Côte d'Ivoire, like in any other shea producing country, a wide range of variation exists in the traditional processing of shea butter, even within the same ethnic group; that leads to an important diversity of shea butters sensorial characteristics [3], [16]. The results of a survey realized all around the country by the author of the present review reported that shea butter consumers of Côte d'Ivoire are generally informed about this diversity which concern shea butter color, odor (fragrance) and texture. Whatever, the first and main criteria of choice concerns the texture $(85.30 \%$ of consumers' interest). About these criteria, consumers identify hard (or compact), doughy and fondant shea butters (Fig. 1), but they mostly prefer the last one $(35.70 \%)$.

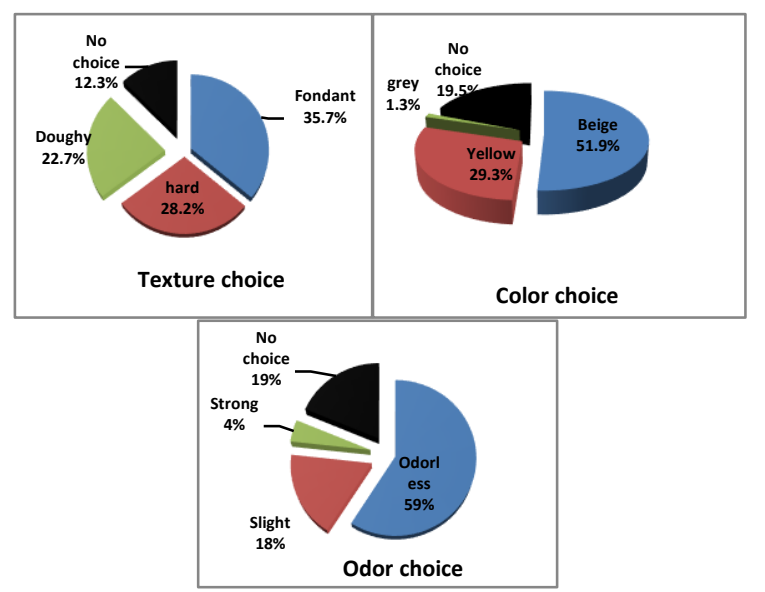

Fig. 1. Ivorian consumers' shea butter color, odor, and texture preferences.
Hence, for most of Ivoirian consumers and in accordance with cosmetics needs of body fat, the best texture for shea butter might be fondant [7]. Indeed, such texture would be adequate and adapted for body care and medicinal compositions (ointments, soap) because it would facilitate active (intrinsic and additional) compounds penetration in the epidermis.

Concerning shea butter color, consumers preferentially choose the beige $(51.90 \%)$ one (Fig. 1) in comparison with the yellow and grey ones. It is worth noting here that, the term beige corresponds to what consumers identify as white or whitish shea butter. Indeed, beige would be the clearer color of traditional (unrefined) shea butter due to the presence of shea kernels natural pigment [17] and to roasting resulting compound named melanoïdine [18], [19]. In reality, the whiteness of shea butter would be generally, the result of a refining [6], [7], [20]; that would also suppose the removing of unsaponifiable fraction with medicinal properties [21] [23]. Some refining proceeds are also used to deodorize shea butter which naturally exhale a typical odor as deeper as kernels fermentation, drying and roasting time are long [3], [24]. In fact, three types of odors (odorless, slight, and strong) are generally described, but the greatest preference is for odorless (58.40\%) shea butter (Fig. 1).

Ivorian use shea butter for three main purposes, but and the best place is recorded by aches treatment $(81.80 \%)$ as shown on Fig. 2. This importance of shea butter in aches treatment and body care by households is in conformity with the increasing exploitation of this fat by cosmetic/pharmaceutical industry. Indeed, according to many authors like Pesquet [4], Hall et al. [3] and Global AAK [7], the interest of such industry for shea butter is linked to various bioactive compounds its unsaponifiable fraction contains. Habit of using shea butter in households could be considered as empiric behaviors transmitted from parents to children. This habit would be the inductor of shea butter exploitation by industrials and would justify their interest for traditional shea butter (Bio-shea butter). Whatever, they might avoid shea butter degradation through refining (deodorization or any other chemical treatment). This precaution would preserve and assure the efficiency of cosmetics and pharmaceutical shea butter products. Shea butter is also use in Ivorian households as cooking oil, mainly in shea producing areas where it would constitute the main cooking fat. In this condition, this shea butter would result from especial careful proceeding, in order to avoid displeasing odor and taste

\section{B. Sensorial Variability and Distribution of Shea Butter on Ivorian Markets}

Traditional shea butters are generally prepared by producers following traditional processes, in shea production areas and then forward on markets (local and elsewhere). Thanks to the wide diversity of origins and producers, marketed shea butters present a great variability of color, odor and texture. Indeed, the collect realized by Megnanou and Niamké [25] was composed of various colors (beige, yellow and grey), odors (rancid, odorless, slight and strong smell) and textures (fondant and hard or compact), either on producing areas markets or elsewhere. Moreover, statistical analyses performed on these sensorial criteria showed that their distribution is not affected by shea butter origin. 
Whatever, as far as color was concerned, the most dominant on all the markets was yellow shea butter $(68 \%)$; the beige one just represented $30 \%$ of the whole collected shea butters (Fig. 2). Grey colored shea butters were at far the less represented fat; they were limited on shea producing area markets. This situation could confirm the statute of bad product attributed to grey shea butter which utilization would be limited to traditional lamp combustible and soap confection, in villages [3].

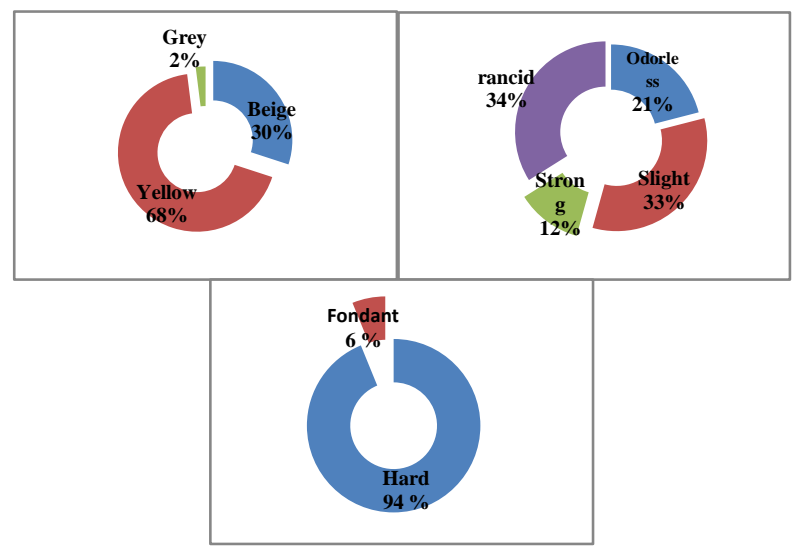

Fig. 2. Shea butter color, odor and texture distribution on Ivorian markets.

About yellow shea butter, it would result from the adding of some Cochlospermum spp. root dye [9], [24], [26], [27]. This process would give an attractive appearance to the butter [9]; and would also preserve it from rancidity because of the presence of high amount of tannins in roots dye [27], [28]. The preservation could explain the wide presence of yellow colored shea butter on Ivorian local markets. Nevertheless, some sellers reported that yellow color would also result from the original whitish shea butter adulteration by synthetic colorant (Personal non-published result). Moreover, author like Omujal [29] and Okullo et al. [30] reported yellow naturally colored shea butter which would be in Uganda (a subspecies Vitellaria nilotica country) and involved in consumers' habit. These natural colors might be due to higher content in $\beta$-carotene [6].

Considering shea butter odor, the greatest percentage on markets is recorded by rancid shea butter with $33.95 \%$ of the whole collected shea butters, while the odorless just represent $20.99 \%$ (Fig. 2). It is important to precise that traditional shea butters exhale various fragrances [3], [9], [26] thickly linked to kernels quality [31], [32], very long drying and roasting times [3], [31], [32]. Rancidity as for it would mainly result from fat (shea butter) storage conditions [33], [34]. Moreover, according to Mohagir et al. [35], rancidity could also be due to the aqueous extraction of traditional processes. However, it would be better using non-rancid shea butter, not only because of its unpleasant fragrance, but also because of eventual presence of mycotoxin as underlined by PfohlLeszkowicz and Castegnaro [36].

If wrapping constitutes the first contact consumers have with selling-food (or non-food) in general [37], about shea butter, the texture was defined as the main criteria of Ivorian consumers [31]. These latest authors also reported that the most common texture on markets is the hard (or compact) one with more than $90 \%$ of the whole marketed shea butter. This situation could explain consumers complain about markets shea butter quality. Indeed, most of them prefer fondant shea butter which would rapidly and easily penetrate epidermis, contrary to the hard ones which would result from adulteration (flours, or animal) as reported in Hall et al. [3].

In summary, this chapter underlined the wide sensorial diversity of traditional shea butter. It also revealed consumers' preferences which could be considered as indicative of sensorial quality. Hence if ordinary consumers always complain about shea butter quality, it would mainly be due to the unconformity between these indicatives (criteria) and the quality of markets shea butters. The solution against this unconformity would be to control shea butter manufacturing process and its conditioning.

The following chapter demonstrates the effect of process variation on shea butter quality. It also underlines the necessity of post-processed shea butter conditioning.

\section{PROCESSING EFFECTS ON SHEA BUtTER QUALITY}

Shea butter quality depends on both its conditioning and its processing [3], [38], Indeed, traditional shea butter process varies from an area to another, and in the same area, from a producer to another [3]. Nevertheless, the whole steps are similar and begin with fruit pulp removing to kernels paste treatment. The latest step constitutes the main point of difference, because shea kernels paste is either boiled in water (most common and easiest) or beat manually until fat appearance. However, each shea processing step deeply affects the fat quality [25], [39].

\section{A. Nuts Drying Effects on Shea Butter Quality}

Some authors like Louppe [40] and Womeni et al. [41] underlined the importance of fresh nuts pre-treatment by bleaching before drying. This pre-treatment would inhibit kernels germination and then reduce enzymatic reaction like triglyceride hydrolysis and unsaturated compounds oxidation. Moreover, according to Aculey et al. [32] shea fresh nuts blanching would facilitate nuts shell removing. Despite of these previous advantages, many producers avoid this step they consider as time wasting. These producers must be informed about the necessity shea nut bleaching which constitutes an essential step to preserve shea kernels and butter quality.

Two (2) modes of shea fresh nuts (bleached or not) drying are reported by several authors, they consist in sun or oven drying. Drying step aims to reduce moisture in order to optimize their storage-life [42], to facilitate nuts treatment [43] and to optimize fat extraction rate. About storage, Codex-Stan [44] recommended a moisture of $9 \%$ for oleaginous like groundnut (grain). However, what is the impact of the drying mode and time on shea butter quality?

\section{Drying Mode Effect on Shea Butter Quality}

Megnanou et al. [31] demonstrated through their study realized in 2013, the significant impact of shea nuts drying mode (either under sun rays or in oven $\left(50{ }^{\circ} \mathrm{C}\right)$ on shea kernels and butters physicochemical characteristics. In fact, their results showed that oven-dried kernels contain at far, slighter moisture $(2.00 \pm 0.01 \%)$ than the sun-dried ones $(19.00 \pm 0.01 \%)$. This value of $2 \%$ is very low compared to that recommended ( $9 \%$ ) by Codex Stan [44] for oleaginous and would suppose shea kernels over-drying. This situation 
could explain the higher peroxide index $\left(5.77 \pm 0.05 \mathrm{mEqO}_{2} / \mathrm{kg}\right)$ and the slighter unsaponifiable mater $(6.65 \%)$ recorded by oven-dried butter, comparatively to sundried ones $\left(2.79 \pm 0.05 \mathrm{mEqO}_{2} / \mathrm{kg}\right.$ and $17.61 \pm 0.05 \%$, respectively for peroxide index and unsaponifiable matter). If physicochemical characteristics are affected, shea butters sensorial properties as for them, are identical in both cases. All these results show and confirm the advantage of sundrying (compared to oven-drying) on preserving the potential pharmaceutical/cosmetic values of shea fat. In fact, according to several authors like Pesquet [4], Louppe. [40] and Joanny [45], the main medicinal virtues (properties) of shea butter would be contained in the unsaponifiable fraction of shea butter. Moreover, the very slight peroxide index resulting from sun-drying would also suggest slighter peroxide compounds which are not indicated in cosmetics.

\section{Sun Drying Time}

Shea nut drying time vary widely from a producer to another and deeply depends on the weather [3]. Nuts are generally exposed to sun ray for time ranging from a week to one (or more) month (s). This variation of time can be justified by the aim (for rural peoples) of getting dehydrated nuts which kernels can easily be separated from the shell. Whereas longer is the nut drying time stronger become shea butter odor [3]; texture and color, as for them are not affected [31]. Nevertheless, it is worth précising that despite of the regular sun-drying, at the end of the first week, some moldy kernel can be observed. The quantity of moldy kernels goes increasing all the drying time long; that could explain the rancid odor of the fourth week shea butter [33], [34] and justify the relative high peroxide index $(10.30 \pm 0.05$ $05 \mathrm{mEqO}_{2} / \mathrm{kg}$ ) in comparison to the first week index $\left(2.79 \pm 0 . \mathrm{mEqO}_{2} / \mathrm{kg}\right)$, The acid index also varies significantly. Both peroxide and acid indexes variation could result from the combined actions of fungal hydrolases and oxidases, as well as sunbeams. Indeed, both factors would cause triglycerides hydrolysis and unsatured fatty acids oxidation [34], [46]. However, the development of moulds on kernels after one week drying returns them potentially harmful [47], [49]. Moreover, Jouany et al. [48] and Galtier et al. [49], underlined the potential danger which could constitute moldy foodstuffs.

\section{B. Kernel Aspect Effects on Shea Butter Quality}

Shea nuts proposed on markets have been generally dried in different conditions (mode and time) and often consist in a melting of recent and older nuts. Hence various qualities of kernels can be found with the same seller in a same recipient (Personal prospection). Sound, moldy, and rotten kernels are then transformed all together into shea butter; consequently, the quality of resulting shea butter is more affected. Indeed, Megnanou and Niamké [25] and Megnanou et al. [31] made the experience of transforming three different categories of kernels (sound, rotten and moldy) and evaluating resulting butters' quality; there were significant difference between sensorial characteristics (Table I), except for the texture. Moldy kernels produced yellow colored and rancid shea butter with; shea butter from rotten kernels was also rancid. If this rancidity is thickly linked to kernels alteration [33], [34], [48], yellow color of moldy kernels shea butter, as for it, would result from a fungal pigment. Indeed, in anhydride conditions, some microorganisms would produce some secondary metabolites like pigment, vitamins and other specific compound depending on the microorganism species [36], [50].

TABLE I. SHEA BUTTER CHARACTERISTICS AS FUNCTION TO KERNELS

\begin{tabular}{cccccc}
\multicolumn{5}{c}{ ASPECTS } \\
\hline $\begin{array}{c}\text { Kernels } \\
\text { aspect }\end{array}$ & Odor & Color & $\begin{array}{c}\text { Acid Index } \\
(\mathrm{mgKOH} / \mathrm{g})\end{array}$ & $\begin{array}{c}\text { Iodine Index } \\
\left(\mathrm{gI}_{2} / 100 \mathrm{~g}\right)\end{array}$ & $\begin{array}{c}\text { Peroxyde } \\
\text { Index. } \\
\left(\mathrm{mEqO}_{2} / \mathrm{kg}\right)\end{array}$ \\
\hline $\begin{array}{c}\text { Sound } \\
\text { Mouldy }\end{array}$ & Normal & Beige & $43.4 \pm 0.0 \mathbf{a}$ & $28.6 \pm 0.2 \mathbf{b}$ & $7.75 \pm 0.0 \mathbf{b}$ \\
Rotten & Rancid & Yellow & $12.2 \pm 0.0 \mathbf{c}$ & $41.0 \pm 0.2 \mathbf{a}$ & $10.00 \pm 0.0 \mathbf{a b}$ \\
& & & $20.8 \pm 0.0 \mathbf{b}$ & $28.3 \pm 0.2 \mathbf{b}$ & $12.86 \pm 0.0 \mathbf{a}$ \\
\hline
\end{tabular}

The presence of yellow fungal pigment could explain the high iodine index $\left(41.05 \pm 0.20 \mathrm{gI}_{2} / 100 \mathrm{~g}\right)$ of shea butter from moldy kernel, compared to sound kernels one $\left(28.60 \pm 0.20 \mathrm{gI}_{2} / 100 \mathrm{~g}\right)$. In this case, this yellow pigment could be an antioxidant compound. Nevertheless, however can be their resulting shea butter color, it would be better ejecting moldy and rotten kernels to avoid eventual intoxication by mycotoxine [48]-[50].

The previous observation and the high acidity of sound kernels shea butter despite of it normal color, suggests that shea butter quality might be defined by considering altogether, its sensorial and physicochemical characteristic.

\section{Roasting Time Effects on Shea Butter Quality}

Kernel roasting contributes to maximize fat extraction rate, but it would also be responsible of shea fat coloration and fragrance development [3].

In traditional processes, shea butter producers generally roast shea kernels until they become deeply dark and smoky; neither roasting time nor kernels quantity is defined. Variability in the latest criteria (time and quantity) constitutes the main problem of shea kernel roasting. Moreover, unbroken kernels (small and large) and broken ones, smaller and larger kernels, are melted and roasted altogether. In these conditions, kernels are not roasted uniformly. As a solution to kernels quantity and size variability, and in order to define adequate roasting time, Megnanou et al. [31], [51] propose to chop uniformly shea kernels (thickness 1-2 mm) before roasting them, under regular stirring. Infact, they studied the effects of kernels (dry kernels were purchased on producing areas markets) roasting time on shea butter quality and deduced that roasting time must be as short as possible to avoid undesirable characteristics. They retained the optimal time of five (5) minutes for $500 \mathrm{~g}$ of chopped kernels roasting at 120 to $150{ }^{\circ} \mathrm{C}$, because shea butter sensorial characteristics went degrading after that roasting time; color becomes deeper (beige to grey), odor varies from sweety musk to rancid. Moreover, shea butter acidity and peroxide index as for them, increased more rapidly while iodine index decreased (Fig. 3). Present results confirm that high temperature would not only induce hydrolysis reactions of glycerides, but also the oxidation of unsaturated fatty acid [34], [52]. 


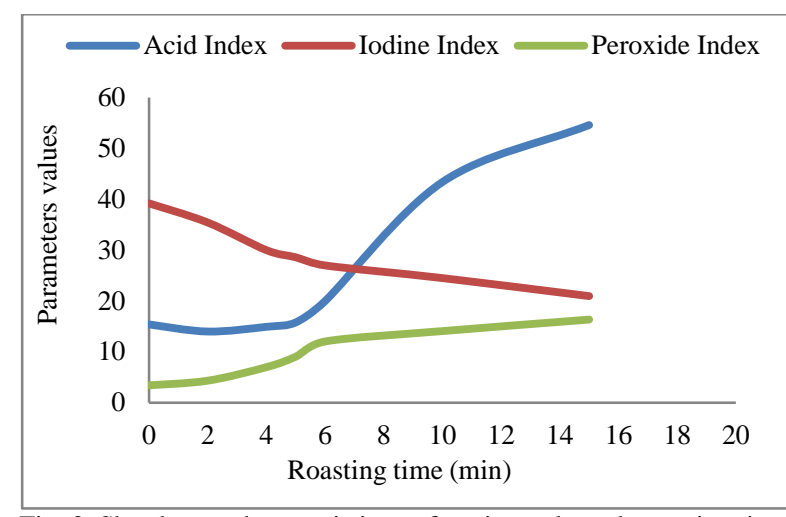

Fig. 3. Shea butter characteristics as function to kernels roasting time.

\section{Shea Butter Wrapping and Its Hygienic Quality}

Wrapping constitute the first contact consumers have with whatever [37]. purchased in commerce; it is most of time used to protect food (or non-food) from environment contaminant [53]. As far as shea butter is concerned, it is preferentially exposed to ambient air to captive people attention; the inconvenient of such conditioning would be for instance, the bad microbiological quality of marketed shea butters [10]. Other authors [54], [55]. Also report that wrapping by itself could constitute the source of food contamination. Effectively, shea butter post-processed conditioning is essential to preserving its safety because the hygienic quality of recipients in which just-processed shea oils are poured would determine its microbiological quality [25]. Indeed, according to these authors, it would be better conserving justprocessed shea oil in sterile wrapping in order to guaranty shea butter microbiological quality; new plastic sachet is also to be avoided. It is worth calling out the whole actors of shea sector and consumers' associations, as well as the person in charge of the public health, on the necessity of improving the hygienic quality of shea butter conditioning. That precaution is essential when considering shea butter implication in households, as antiseptic balm on wounds, as eye drops for some eye affections and for newborns umbilical wounds healing.

At the end of this chapter, the optima shea butter processing factors to be retained are fresh nuts bleaching, sun drying, one week as maximal drying time, exclusively sound kernels (rotten and moldy ones must be ejected) and five minutes to roast $500 \mathrm{~g}$ of chopped shea kernels. In addition, newly processed shea oil must be conserved in clean (sterile, if possible) recipients. Indeed, fresh nut bleaching inhibit microorganism's development and nuts germination, when sun-drying for one week (maximum) and kernels roasting for five minutes, induce lower free fatty acids and peroxide compounds, and also very high unsaponifiable matters (cosmetic/pharmaceutical industry main interest). Such short drying and roasting time would also reduce/avoid moulds development on kernels and prevent shea butter from rancidity, respectively.

The previous shea nuts treatment and shea butter conditioning are not respect by producers; that could justify the wide variability of traditional shea butter quality (sensorial, physicochemical, and microbiological). Nevertheless, both food and cosmetic/pharmaceutical industries interest (and demand) for traditional shea butter are going increasing. What can justify this increasing interest?

\section{Traditional Shea Butter Properties AND POTENTIALS}

The previous chapter has drawn the thick correlation between shea butter sensorial/physicochemical properties and its processing variation. However, if the choice of households is essentially based on shea butter sensorial properties, industrials as for them mainly consider the physicochemical aspects. Hence, as function to each industry purpose, several criteria have been defined according to both Codex-Alimentarius standards, and also to industries (food, cosmetic, pharmaceutical, etc.) exigencies. For instance, while cosmetic industry generally focuses on shea butter unsaponifiable content and compounds, when food industry is essentially interested by nutritive and dietetic compounds. Such variability in industries exigencies might be correlated with shea butter wide potentiality of exploitation, as raw material. About traditional shea butter potentialities of exploitation, they are thickly linked to the physicochemical and biochemical properties [4], [5], [40]. of beige and yellow shea butter, as the grey one is considered as a bad product.

The present information result from Megnanou et al. [56]. Publication on traditional shea butters samples collected on the markets of shea producing areas and elsewhere in Côte d'Ivoire. It is worth recalling here that traditional shea butters are forwarded on markets where they are often adulterated with several products (flours, ash, water, animal, or other vegetable fats) [3], [57].

\section{A. Physicochemical and Biochemical Characteristics of Beige and Yellow Marketed Shea Butters}

Despite of their various origins, the whole markets shea butters (beige and yellow) present characteristics of conventional edible oils [58], as far as their specific gravity and refractive index are concerned. Furthermore, all they could be classified as non-drying fats in view to their refractive index value [59]. Hence traditional shea butter could be potentially exploited in food industry, mainly as texturing fat [60]. because of their viscosity (86-92 mPas, $40{ }^{\circ} \mathrm{C}$ ) which is, at far higher than those of commonly used vegetable oils (75 mPas) [61], [62]. It is important to notice that this relative high viscosity can be explained by the naturally solid consistence of West African shea butter which would result from the most important amount of satured fatty acid (> $50 \%$ ), as shown on Table II.

This solid consistence of shea butter is continuously affected by heating at increasing. Such behaviours are in conformity with.

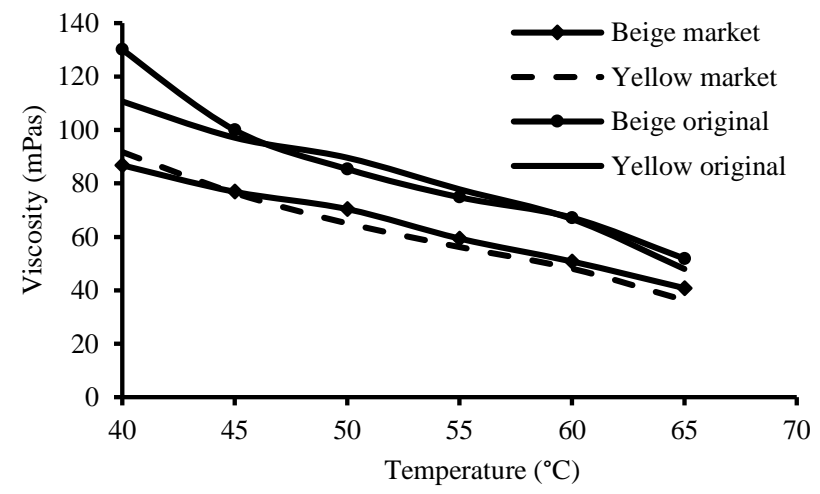

Fig. 4. Effect of temperature on market and original manufactured shea butters viscosity. 
TABLE II: PHYSICO-CHEMICAL AND BIOCHEMICAL PROPERTIES OF TRADITIONAL SHEA BUTTERS

\begin{tabular}{|c|c|c|c|c|}
\hline Parameters & Beige market & $\begin{array}{l}\text { Yellow } \\
\text { market }\end{array}$ & Beige original & $\begin{array}{c}\text { Yellow } \\
\text { original }\end{array}$ \\
\hline Specific gravity $\left(40^{\circ} \mathrm{C}\right)$ & $0.91 \pm 0.0^{\mathrm{ab}}$ & $0.92 \pm 0.0^{\mathrm{a}}$ & $0.89 \pm 0.0^{\mathrm{b}}$ & $0.88 \pm 0.0^{\mathrm{c}}$ \\
\hline Refractive index $\left(40^{\circ} \mathrm{C}\right)$ & $1.46 \pm 0.0^{\mathrm{a}}$ & $1.46 \pm 0.0^{\mathrm{a}}$ & $1.46 \pm 0.0^{\mathrm{a}}$ & $1.46 \pm 0.0^{\mathrm{a}}$ \\
\hline Viscosity (mPas) $\left(40^{\circ} \mathrm{C}\right)$ & $86.78 \pm 0.3^{\mathrm{d}}$ & $91.75 \pm 0.2^{\mathrm{c}}$ & $130.10 \pm 5.0^{\mathrm{a}}$ & $110.69 \pm 5.2^{\mathrm{b}}$ \\
\hline SFA $(\%)$ & $63.00 \pm 0.2^{\mathrm{a}}$ & $56.00 \pm 0.2^{\mathrm{c}}$ & $63.00 \pm 0.2^{\mathrm{a}}$ & $62.00 \pm 0.2^{\mathrm{b}}$ \\
\hline UFA $(\%)$ & $37.00 \pm 0.1^{\mathrm{c}}$ & $44.00 \pm 0.1^{\mathrm{a}}$ & $37.00 \pm 0.1^{\mathrm{c}}$ & $38.00 \pm 0.1^{\mathrm{b}}$ \\
\hline Unsaponifiable matter $(\%)$ & $03.18 \pm 0.0^{\mathrm{b}}$ & $01.80 \pm 0.0^{\mathrm{d}}$ & $03.76 \pm 0.0^{\mathrm{a}}$ & $02.20 \pm 0.0^{\mathrm{c}}$ \\
\hline Palmitic acid (\%) & $23.00 \pm 0.1^{\mathrm{b}}$ & $18.00 \pm 0.1^{\mathrm{d}}$ & $24.00 \pm 0.0^{\mathrm{a}}$ & $22.00 \pm 0.1^{\mathrm{c}}$ \\
\hline Stearic acid (\%) & $40.00 \pm 0.1^{\mathrm{a}}$ & $38.00 \pm 0.1^{\mathrm{c}}$ & $39.00 \pm 0.0^{\mathrm{b}}$ & $40.00 \pm 0.1^{\mathrm{a}}$ \\
\hline Oleic acid (\%) & $32.00 \pm 0.1^{\mathrm{c}}$ & $39.00 \pm 0.1^{\mathrm{a}}$ & $32.00 \pm 0.0^{\mathrm{c}}$ & $34.00 \pm 0.1^{\mathrm{b}}$ \\
\hline Linoleic acid (\%) & $05.00 \pm 0.0^{\mathrm{a}}$ & $5.00 \pm 0.0^{\mathrm{a}}$ & $05.00 \pm 0.0^{\mathrm{a}}$ & $04.00 \pm 0.0^{\mathrm{b}}$ \\
\hline
\end{tabular}

Values are expressed as mean \pm SD. Means in the lines with no common superscript differ significantly $(\mathrm{p}<0.05)$

Arrhenius law relative to fats in general. decreases exponentially with increasing of temperature. similitude in the evolution of the viscosity for all the samples. This situation could also suggest similarity in fatty acids composition, for both marketed and original shea butters. However, such rheological property (viscosity/temperature) of the studied shea butters could be exploited in cosmetic industries for emulsions making [60].

All the spectra presented the same profile with a wide peak from 200 to $300 \mathrm{~nm}$ and then a rapid decrease of absorbance in the interval of 300 to $500 \mathrm{~nm}$ (Fig. 5). The wide peak appeared between 200 and $300 \mathrm{~nm}$ would suggest the presence of either ethylenic bonds with conjugation or carbonyl compounds [63]. The strong decrease of absorbance as for it would presume the presence of UV-filter compounds in shea butter samples [64]. This would justify the great interest of cosmetic and pharmaceutical industries for shea butter and would then constitute an advantage for using the studied shea butters in cosmetics formulations as UV protectors against carcinogenic UV (B and A). The similitude between market and original samples spectra could not only suppose the use of the same shea variety but also the same manufacturing process. UV spectra could then be considered as a distinctive (specific) characteristic allowing any shea butter traceability (as function to the variety and/or the manufacturing process).

The visible and near infrared spectrum shea butters samples is shown in Fig. 5. The visible domain of this spectrum showed maximum absorbance at $450 \mathrm{~nm}$ for yellow marketed and original shea butters, and a relatively weak peak at $700 \mathrm{~nm}$ for market yellow shea butter (Fig. 5C).

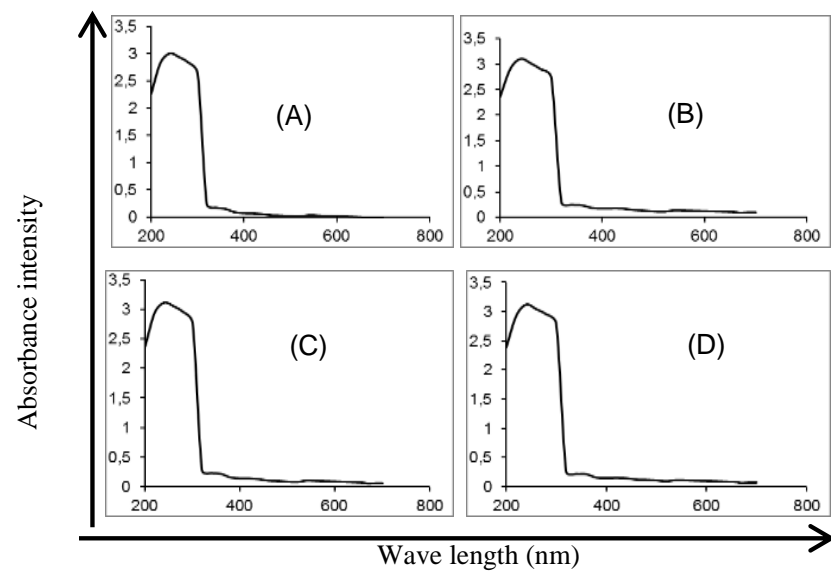

Fig. 5. UV-Visible spectrum of market and original manufactured shea butters: (A): beige market; (B): yellow market; (C): beige original; (D): yellow original.
If the absorbance at $450 \mathrm{~nm}$ would suggest the presence of carotenes compounds in both samples [65], the peak at 700 $\mathrm{nm}$ as for it would suggest the presence of chlorophyll. These observations would confirm yellow shea butters high Lovibond color value in yellow light. Very slight absorbance was also observed for beige shea butters at 450-500 and would then suppose the presence of carotene in weak amount. As for the near infrared domain of the spectrum, it showed four main peaks at 1200, 1400, 1725 and $2150 \mathrm{~nm}$ (Fig. 6). About the peaks observed at 1200, 1400, 1725 and $2150 \mathrm{~nm}$, they would be related to $\mathrm{C}-\mathrm{H}$ stretching $2^{\text {nd }}$ overtone (oil), C$\mathrm{H}$ stretching $1^{\text {st }}$ overtone (oil), CO stretching $1^{\text {st }}$ overtone (oil), and $\mathrm{C}-\mathrm{H}$ bending $2^{\text {nd }}$ overtone (oil), respectively [66]. The peaks at 1200 and 1400 would indicate the presence of hydrocarbon, when fatty acids (FFA) would be characterized by the peak at $1725 \mathrm{~nm}$ (CO stretching $1^{\text {st }}$ overtone). As for the peak (vibration of $\mathrm{C}-\mathrm{H}$ cis-unsaturation bonds) observed at $2150 \mathrm{~nm}$, it would suppose the presence of unsaturated compound such as unsaturated fatty acids [67]. This previous information (UV and IR spectra) would suggest the presence of hydrocarbon, unsaturated compound, fatty acids and compounds protecting against damages sun rays could cause (allergy and cancer).

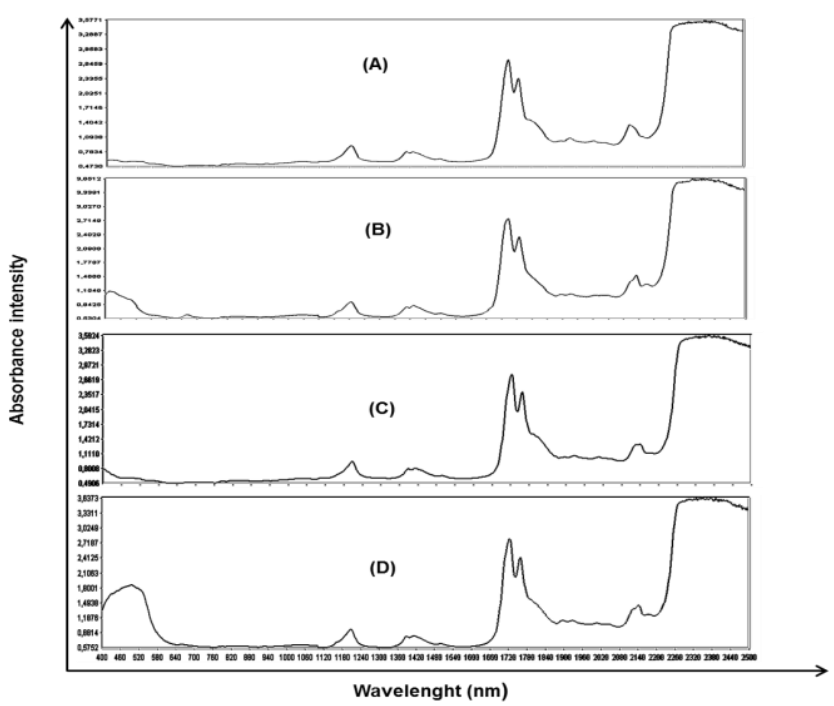

Fig. 6. Near infrared (NIR) spectrum of market and original manufactured shea butters: (A): beige market; $(\mathrm{B})$ : yellow market; $(\mathrm{C})$ : beige original; (D): yellow original. 


\section{Biochemical and nutritive properties of beige and yellow marketed shea butters}

Biochemical parameters showed significant statistical difference $(\mathrm{p}<0.05)$ for the samples analyzed (Table III).

Intrinsic biochemical parameters such as unsaponifiable matter varies from 1.78 to $3.79 \%$ and are higher than those reported for other high value solid fats such as coconut kernel (0.2-0.4\%), palm kernel (0.3-0.5\%) and cocoa (0.5-1\%) [68]. Therefore, beige and yellow market and original shea butters could be used as a good source of stabilizers in cosmetic and food industry [3], [4], [7], [69].

Chromatographic profiles of fatty acids composition of the samples are given in Fig. 7.

Fatty acid proportions of the studied shea butters highlighted the presence of four main compounds which are palmitic $(18.00-24.00 \%)$, stearic $(38.00-40.00 \%)$, oleic (32.00-39.00\%) and linoleic (4.00-5.00\%) acids (Table III). It is worth précising here that shea butter contains other fatty acids but the main in content are the previous cited. These other fatty acids were materialized on the spectrum by peak with very slight intensity.

However, unsaturated fatty acids (UFA) of the studied shea butters were essentially made up of oleic and linoleic acids. The saturated fatty acids (SFA) as for them consisted in palmitic and stearic acids. It was remarked that the proportion of oleic acid in all the shea butter samples, was more important than in the literature. If for markets shea butters, this situation could be justified by the adulteration (other fat adding), about original samples, it would be difficultly justified. However, the proportions of UFA and SFA were $37.00-44.00 \%$ and $56.00-63.00 \%$, respectively. This amount of SFA (>50\%) would justify the solid state of the studied shea butters at ambient temperature [70]. Indeed, presence of saturated fatty increases the melting point of fats and oils [71] because of their melting points $(62.7-69.6 \%)$ which are at far higher than of unsaturated (-6.5-13.0\%) ones [72]. In view of the fatty acid profiles, beige and yellow market and original shea butters could be categorized as stearic-oleic fats such as cocoa butter and mango kernel oil [61]. Therefore, the studied shea butters could be used in food industry for frying due to the thermal stability of oleic acid and for margarine making due to the melting point of stearic acid [69], [73]. Moreover, the important oleic acid content (32.00-39.00\%) could be advantageous for "oléine de karité" production. This product consists in shea butter liquid fraction and is widely exploited and traded in Burkina Faso. Furthermore, the presence of linoleic acid could be useful in cosmetic industry to decrease trans-epidermal water loss and to eliminate scaly lesions common in patients with essential fatty acid deficiency [74]. The presence of both oleic and linoleic acids which are essential fatty acids, would also suggest a potential beneficial use as edible fat.

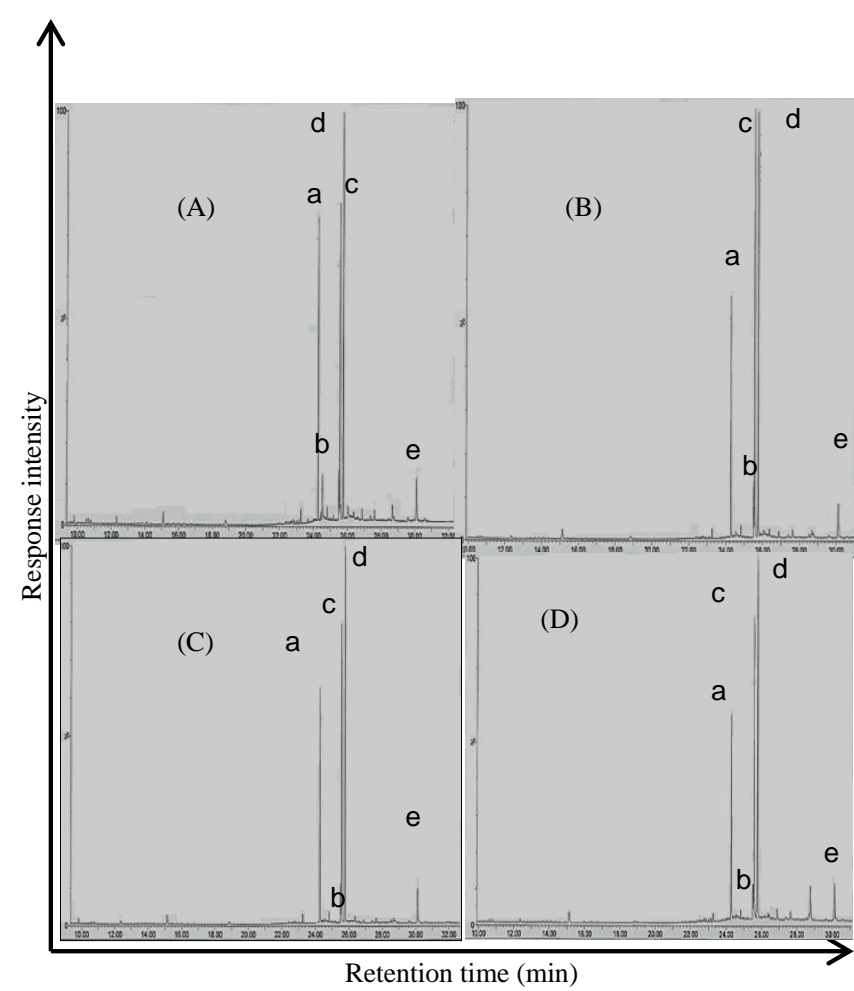

Fig. 7. Gas chromatographic profiles of market and original manufactured shea butters fatty acids: (A): beige market; (B): yellow market; (C): beige original; (D): yellow original; (a): palmitic acid; (b): linoleic acid;

(c): oleic acid; (d): stearic acid; (e): erucic acid (internal standard).

In addition to such interesting fatty acids profile, the whole traditional shea butter analyzed in the present study contained interesting minerals like calcium, iron, zinc, copper and magnesium, but also high amounts of heavy metals like lead (4.84 to $91.60 \mathrm{mg} / \mathrm{kg}$ ) and nickel (1.27 to $3.07 \mathrm{mg} / \mathrm{kg}$ ), as shown in Table IV.

TABLE III: BIOCHEMICAL AND NUTRITIVE PROPERTIES OF BEIGE AND YELLOW MARKET AND ORIGINAL SHEA BUTTERS

\begin{tabular}{ccccc}
\hline Parameters & Beige market & Yellow market & Beige original & Yellow original \\
\hline $\begin{array}{c}\text { Unsaponifiable } \\
\text { matter (\%) }\end{array}$ & $03.18 \pm 0.01^{\mathrm{b}}$ & $01.80 \pm 0.01^{\mathrm{d}}$ & $03.76 \pm 0.02^{\mathrm{a}}$ & $02.20 \pm 0.05^{\mathrm{c}}$ \\
Palmitic acid (\%) & $23.00 \pm 0.10^{\mathrm{b}}$ & $18.00 \pm 0.10^{\mathrm{d}}$ & $24.00 \pm 0.01^{\mathrm{a}}$ & $22.00 \pm 0.10^{\mathrm{c}}$ \\
Stearic acid (\%) & $40.00 \pm 0.10^{\mathrm{a}}$ & $38.00 \pm 0.10^{\mathrm{c}}$ & $39.00 \pm 0.01^{\mathrm{b}}$ & $40.00 \pm 0.10^{\mathrm{a}}$ \\
Oleic acid (\%) & $32.00 \pm 0.10^{\mathrm{c}}$ & $39.00 \pm 0.10^{\mathrm{a}}$ & $32.00 \pm 0.01^{\mathrm{c}}$ & $34.00 \pm 0.10^{\mathrm{b}}$ \\
Linoleic acid (\%) & $05.00 \pm 0.01^{\mathrm{a}}$ & $05.00 \pm 0.01^{\mathrm{a}}$ & $05.00 \pm 0.01^{\mathrm{a}}$ & $04.00 \pm 0.01^{\mathrm{b}}$ \\
SFA (\%) & $63.00 \pm 0.20^{\mathrm{a}}$ & $56.00 \pm 0.20^{\mathrm{c}}$ & $63.00 \pm 0.20^{\mathrm{a}}$ & $62.00 \pm 0.20^{\mathrm{b}}$ \\
UFA (\%) & $37.00 \pm 0.10^{\mathrm{c}}$ & $44.00 \pm 0.10^{\mathrm{a}}$ & $37.00 \pm 0.10^{\mathrm{c}}$ & $38.00 \pm 0.10^{\mathrm{b}}$ \\
\hline
\end{tabular}

Values are expressed as mean \pm SD. Means in the lines with no common superscript differ significantly $(\mathrm{p}<0.05)$

\begin{tabular}{ccccccccc}
\multicolumn{8}{c}{ TABLE IV: Mineral ChARACTERISTICS OF MARKED SHEA ButTER } \\
\hline \multirow{2}{*}{ Color } & $\mathrm{Cu}$ & $\mathrm{Fe}$ & $\mathrm{Pb}$ & $\mathrm{Ni}$ & $\mathrm{Zn}$ & $\mathrm{Ca}$ & $\mathrm{Na}$ & $\mathrm{Mg}$ \\
\hline Beige & $15.23 \pm 0.0$ & $28.76 \pm 0.0$ & $10.12 \pm 0.0$ & $3.07 \pm 0.0$ & $28.05 \pm 0.0$ & $289.50 \pm 0.0$ & $70.96 \pm 0.0$ & $19.39 \pm 0.0$ \\
Yellow & $5.82 \pm 0.0$ & $67.17 \pm 0.0$ & $91.60 \pm 0.0$ & $1,27 \pm 0.0$ & $34.35 \pm 0.0$ & $340.65 \pm 0.0$ & $95.90 \pm 0.0$ & $88.74 \pm 0.0$ \\
\hline
\end{tabular}


Difference in beige and yellow shea butters contents could be the result of many manipulations of the latest. Indeed, many traders would add yellowish pigments (natural or not) to beige shea butter in order to increase their conservation time. This situation could explain the high amount of yellowish shea butters on markets. Moreover, according to Hall et al. [3], marketed shea butter would sometime be adultery with wood ash and various flours. This latest raison could justify the general high amounts of minerals in both beige and yellow shea butters. However, the presence of minerals like calcium, zinc and magnesium would be of great interest for women (in pregnant) and children feeding. As for the presence of heavy metal like lead, it would result from shea kernels and butter exposure to cars exhaust fumes [75]. It is worth noting that peasants sometime, spread shea nuts on sidewalks for drying. Shea butters as for them, are exposed (even if in recipients) generally non-covered to the atmospheric air and dust.

\section{B. Microbiological Characteristics of Traditional Shea Butters}

Microbiological characteristics of traditional shea butters drown on table $\mathrm{V}$, reveale a relative high level of contamination by microorganisms' germs. Such situation could be derived from bad conditioning of marketed shea butters. Indeed, atmospheric air, cars exhaust fumes and dust could be vectors of microbial germs [33], [47]. Results were alarming though samples aerobic mesophile bacteria $\left(2.7 \times 10^{+5}\right.$ bacteria/g of shea butter $)$ total coliforms $(2 \times 10+2$ bacteria/g of shea butter), yeast and moulds $(10+4$ germs $/ g$ of shea butter) registered more important values than standards for edible fats admit (Table V). Some samples contained pathogen germ as Salmonella (10 bacteria/g of shea butter). It is worth précising the importance of shea butter hygienic conditioning at regard to its usual and current utilizations in household. For instance, without pre-heating to eliminate germs, shea butter is used as wounds curing pomade and baby ointment [3].

Considering such utilizations and the eventual presence of pathogen microorganisms, it would be worth taking more care for shea butter conditioning in order to preserve consumers' health and then guaranty its exploitation by food, cosmetic and pharmaceutical industries.

TABLE V. MicRoBIOLOGICAL CHARACTERISTICS OF MARKED SHEA BUTTER

\begin{tabular}{cccc}
\multicolumn{4}{c}{ BUTTER } \\
\hline Identified microorganisms & Standard & $3 \times$ Standard & Marketed shea butter \\
\hline Mesophiles bacteria/g & $<1 \times 10^{+4}$ & $<3 \times 10^{+4}$ & $2.7 \times 10^{+5}$ \\
Total Coliforms /g & $<25$ & $<75$ & $2 \times 10^{+2}$ \\
Yeast and moulds/g & $<10$ & $<30$ & $1 \times 10^{+4}$ \\
Salmonella $/ g$ & 0 & 0 & 10 \\
\hline
\end{tabular}

It might be retained from this chapter that the main difference between beige and yellow shea butters resides in the presence of carotene and chlorophyll. These compounds could confer to the yellow shea butter, a higher resistance to oxidation. However, the values of specific gravity and viscosity confer to both beige and yellow shea butters, good characteristics for edible vegetable fat. Moreover, their essential fatty acid (linoleic acid) and the presence of minerals like calcium, magnesium and zinc would profile a benefic exploitation in human nutrition, and then in food industry. Cosmetic and pharmaceutical industries interest in the studied shea butters would be linked to the $\mathrm{pH}$ value in conformity with the human body one, the relatively high unsaponfiable content, mineral such as zinc, the melting point, the very slight absorption of UV-A and UV-B and the presence of hydrocarbon such as karitene. Above all, the similitude between the spectra ultra-violet and infrared of the whole studied samples would suggest the spectra to be essential parameters for shea butter traceability. Considering such potentialities of traditional shea butter, the contamination by heavy metal and microbiological germ might suggest the adoption of adequate hygienic conditioning. Such attitude would guaranty the trading/exportation of this fat which would be the main source of money women of shea producing area, and consequently monetary currency for shea producing countries.

\section{OPTIMIZED SHEA BUtTER PRODUCTION, A GREAT POTENTIAL FOR INDUSTRIES}

As recall, ordinary traditional shea butters present a wide variability (of quality) which is thickly linked to process diversity. Most of time, this fat is not in conformity with consumers' (households, traders, and industrials) approach about shea butter quality. Necessity of standardizing the traditional process is essential though abroad consumers' demand of bio-product (traditionally extracted shea butter) goes increasing. This demand also concerns cosmetic and pharmaceutical industries because of shea butter intrinsic medicinal virtue which would be preserved with its traditional extraction [11].

Optimized shea butter can, be considered as solution to the previous demand. Indeed, previous results of Megnanou et al [51] have drawn the optimized shea butter characteristics which are in conformity with both consumers' sensorial criteria and trade/exportation exigencies. Such butter results from the optimization of traditional process by defining/precising optimal condition of nuts drying, kernels and kernel roasting. The optimized process has been deducted from the study realized in chapter III; it can be considered as a standardization of the traditional aqueous process.

Optimized shea butter is prepared by bleaching for 20 minutes, nuts of $10 \mathrm{~kg}$ of matures fruits (with very smooth pulp) in two equivalent volumes of boiling. It is important to note that pulp of the whole fruits is removed (by simple pressing of fingers) because of variability in its thickness from fruit to another [3]. After bleaching, fibrous tissue covering nuts is removed (because it retains lot of boiling water) and nuts are sun-dried for one (1) week; shells can easily be cracked. Kernels are then, extracted from nuts, chopped with a kitchen chopper, and then roasted at 120 to $150{ }^{\circ} \mathrm{C}$ for $5 \mathrm{~min}$ (by part of $500 \mathrm{~g}$ ). The roasted kernels are ground with an electric grinder and kernels paste is boiled for one hour in 2 equivalent volumes of distilled water for the beige shea butter and 2 equivalent volumes of a decoction of Cochlospermum. tinctorium roots $(1 \mathrm{~kg}$ of roots boiled for one hour in $10 \mathrm{~L}$ of distilled water), for the yellow shea butter. Floating oil of the boiling solution is delicately collected in a clean glass-pot. 
About floating oil, Megnanou and Niamké [57] suggest avoiding another heating for residual water elimination, as proposed by Megnanou et al. [51]. In fact, first authors obtained, by avoiding final shea oil heating, shea butters with acid $(0.280 \pm 0.001$ and $0.140 \pm 0.001 \mathrm{mgKOH} / \mathrm{g})$ and peroxide $\left(0.960 \pm 0.001\right.$ and $\left.1.01 \pm 0.001 \mathrm{mEqO}_{2} / \mathrm{kg}\right)$ indexes at far slighter than those (10.51 and $11.94 \mathrm{mgKOH} / \mathrm{g} ; 5.77$ and $2.79 \mathrm{mEgO} 2 / \mathrm{kg}$ ) obtained by the second ones. Such situation can be explained by heating temperature (more than $100^{\circ}$, for water boiling) which is high and would induce fat glycerides and unsaturated compounds (fatty acids) hydrolysis and oxidation, respectively [34].

Optimized shea butters presented different characteristics as function to color.

\section{A. Sensorial Characteristics of Optimized Shea Butters}

Both beige and yellow optimized shea butters are fondant texture and exhale a moderate (slight) shea characteristic odor. This typical odor can be compared to sweety musk fragrance and would suppose non-rancidity. Such fat can directly be used as body pomade without deodorization and/or perfume adding; consumers would then benefice of the whole natural virtues of shea butter. Optimized shea butter choice linked to its color will depend on consumers' own approach. However, yellow optimized shea butter would be more indicated for medicinal purpose because of $C$. tinctorium involvement. Indeed, according to Diaw [76] this plant is widely exploited by traditional healers in many diseases' treatment.

\section{B. Physicochemical and Biochemical Characteristics of Optimized Shea Butters}

\section{Physicochemical Characteristics of Beige and Yellow Optimized Shea Butters}

Beige and yellow optimized shea butters present significant difference $(p<0.05)$, on basis of physicochemical characteristics, except for peroxide and refractive index (Table VI). Above the whole samples got acid $(0.280 \pm 0.001$ and $0.140 \pm 0.001 \mathrm{mgKOH} / \mathrm{g})$ and peroxide $(0.960 \pm 0.001$ and $1.01 \pm 0.001 \mathrm{mEqO}_{2} / \mathrm{kg}$ ) indexes which are considered as fat quality characteristics with moisture content, very low. This would suppose a good aptitude for exportation/international trade though the fat also contained just $0.2 \%$ of moisture as recommended by UEMOA [8] for trade purpose. Specific gravity measured at $40{ }^{\circ} \mathrm{C}$ is $0.87 \pm 0.00$ and $0.92 \pm 0.00$, respectively for the beige and the yellow shea butter. Such values added to those of the refractive index (1.454 and 1.453, respectively) and the viscosity $(73.66 \pm 0.20$ and $96.00 \pm 0.20 \mathrm{mPas}$ ) would confer and confirm the quality of conventional edible vegetable oils to both beige and yellow optimized shea butters [58], [64].

TABLE VI: PHYSICOCHEMICAL CHARACTERISTICS OF THE OPTIMIZED

\begin{tabular}{ccc}
\multicolumn{3}{c}{ SHEA BUTTERS } \\
\hline Parameters & Beige & Yellow \\
\hline Specific gravity $\left(40^{\circ} \mathrm{C}\right)$ & $0.87 \pm 0.0 \mathrm{~b}$ & $0.92 \pm 0.01 \mathrm{a}$ \\
Refractive index $\left(40^{\circ} \mathrm{C}\right)$ & $1.45 \pm 0.0 \mathrm{a}$ & $1.45 \pm 0.0 \mathrm{a}$ \\
Viscosity $(\mathrm{mPas})\left(40^{\circ} \mathrm{C}\right)$ & $73.66 \pm 0.2 \mathrm{~b}$ & $96.00 \pm 0.20 \mathrm{a}$ \\
Activation energy $(\mathrm{Kj} / \mathrm{mol})$ & 46.81 & 50.43 \\
Colour $(\mathrm{Ly})$ & $3.40 \pm 0.0 \mathrm{~b}$ & $3.90 \pm 0.0 \mathrm{a}$ \\
$\mathrm{pH}\left(25^{\circ} \mathrm{C}\right)$ & $06.50 \pm 0.3 \mathrm{~b}$ & $06.78 \pm 0.3 \mathrm{a}$ \\
Acid Index $\mathrm{mgKOH} / \mathrm{g})$ & $0.280 \pm 0.00 \mathrm{a}$ & $0.140 \pm 0.00 \mathrm{~b}$ \\
Peroxide Index $\left(\mathrm{mEgO}_{2} / \mathrm{kg}\right)$ & $0.960 \pm 0.00 \mathrm{a}$ & $1.010 \pm 0.00 \mathrm{a}$ \\
Iodine index $\left(\mathrm{gI}_{2} / 100 \mathrm{~g}\right)$ & $52.64 \pm 0.2 \mathrm{~b}$ & $53.06 \pm 0.2 \mathrm{a}$ \\
\hline
\end{tabular}

Furthermore, such shea butters could be classified as nondrying fats in view to their refractive index value [59]. This property would disqualify them for varnish manufacturing in chemical industry, despite of their relatively high iodine value (52.64 \pm 0.20 and $53.06 \pm 0.20 \mathrm{gI}_{2} / 100 \mathrm{~g}$ ) compared to that of marked shea butters reported by Megnanou et al. [51]. This iodine index value would suggest an interesting amount of unsatured fatty acids. This value would also confirm the advantage of improving Megnanou et al. [51] method by suppressing final oil heating (in order to eliminate residual water).

About viscosity, those of liquids as vegetable oil are commonly perceived as thickness, or resistance to pouring [77]. Beige shea butter of the present experience was less viscous than the yellow one, probably due to Chochlospermum tinctorium dye mucilage [78]. In addition, this latest fat viscosity was higher than the mean value (75 mPas) of most vegetable oils [64]. This physical property linked to the solid state of shea butters could be used in food and cosmetic industry to confer an adequate texture to final fat products [61]. Moreover, the profile of the temperature effect on viscosity depicted in Fig. 8, could be exploited by everyone, in order to get exactly the viscosity according to the utilization; the same scheme is valuable for the specific gravity of shea butter as showed on Fig. 9. It is worth noting here that each sample observed a typical variation of viscosity $\left(\mathrm{y}=0.0627 \mathrm{x}^{2}-8.6818 \mathrm{x}+318.74\right.$ and $\mathrm{y}=0.106 \mathrm{x}^{2}-13.99 \mathrm{x}$ +485.19 , beige and yellow) and gravity $\left(\mathrm{y}=0.0002 \mathrm{x}^{2}-\right.$ $0.0205 x+1.4299$ and $y=-0.0037 x+1.0684$, beige and yellow) which was materialized by the mathematical equations on the figures.

In summary, the value of viscosity decreases (90.41 to 20.01 and 125.37 to $23.55 \mathrm{mPas}$, respectively for beige and yellow shea butters) continuously when the temperature increases from 35 to $65^{\circ} \mathrm{C}$ and would confirm the Arrhenius law [62] which indicates that the viscosity of fats decreases exponentially with increasing of temperature. It was also observed a relative similitude in the evolution of the viscosity for all the samples. This situation could also suggest similarity in fatty acids composition, for both beige and yellow shea butters.

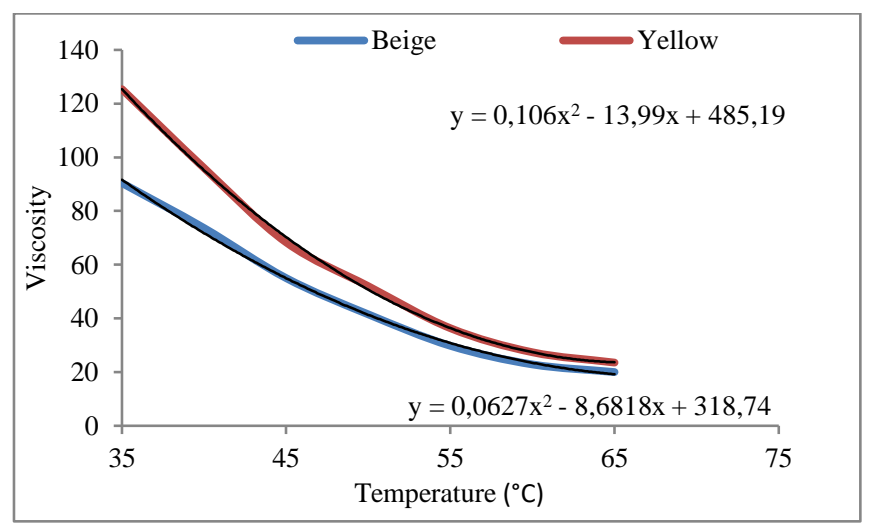

Fig. 8. Optimized shea butter viscosity variation as function to the heating temperature. 


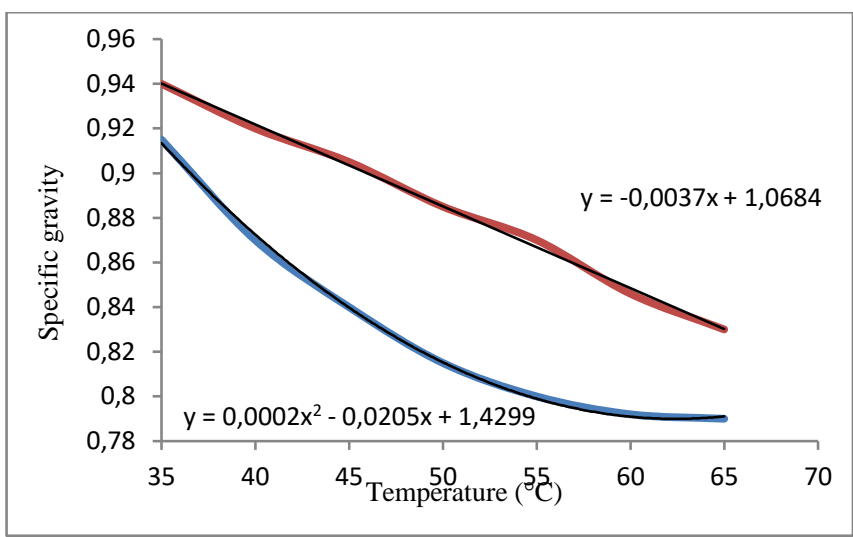

Fig. 9. Optimized shea butter specific gravity variation as function to the heating Temperature.

However, such rheological property (viscosity/temperature and specific gravity/temperature) linked to the relatively important energy of activation (46.81 and $50.43 \mathrm{kJj} / \mathrm{mol}$ ) of the studied shea butters could be exploited in cosmetic industries for emulsions making [60]. Above all, the $\mathrm{pH}$ of the studied shea butters would be indicated for such industry, mainly for body care because of its values $(06.50 \pm 0.30$ and $06.78 \pm 0.30)$ which around the human body $\mathrm{pH}$ [79].

Spectra (Near infrared and UV-visible) of both shea butter presented, at the whole, the same profile, respectively (Fig. 10 and 11); which was in general similar to those of marked and original traditional shea butter seen on the chapter III.

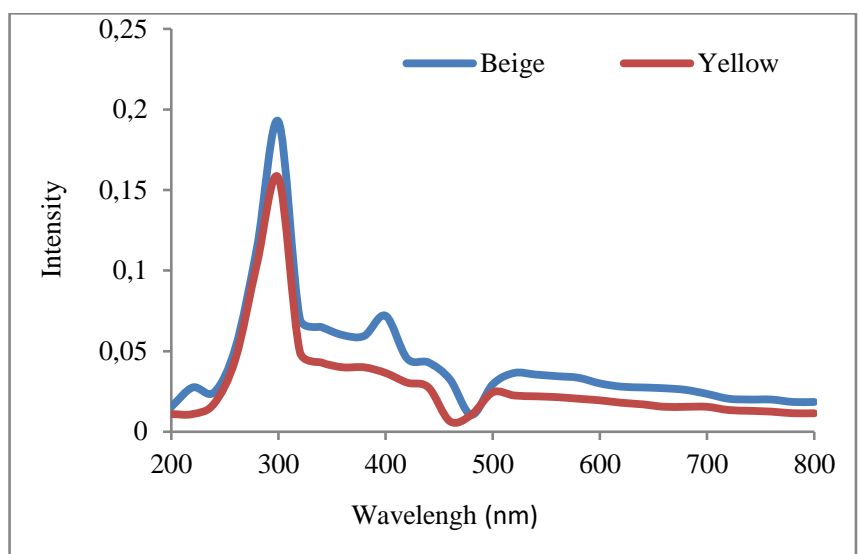

Fig. 10. UV-Visible spectrum of optimized shea butters.

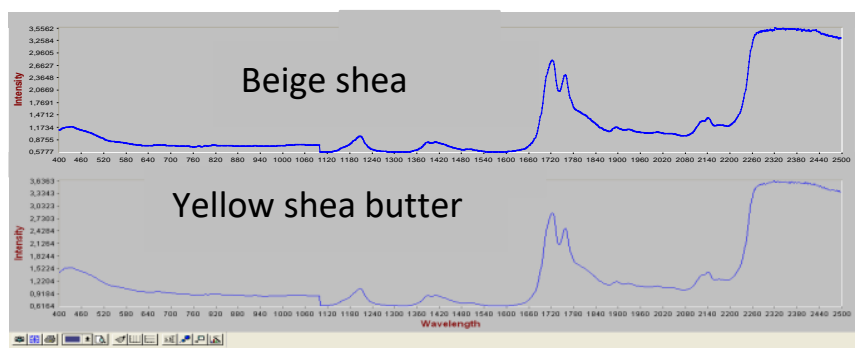

Fig. 11. Near infrared spectrum of the optimized beige shea butter.

In summary, and as a recall, both beige and yellow optimized shea butter would contain molecular bearing ethylenic bonds with conjugation and carbonyl compounds [63]. This would indicate the presence of fatty acids (satured and not). These butters would also contain UV-filter compounds (molecular) materialized by the rapid decrease of the absorbance ( 0.15 to 0.05 and 0.2 to 0.075 , respectively for yellow and beige shea butter) from 300 to $400 \mathrm{~nm}$ [64].
Moreover, another interesting peak were observed at $400 \mathrm{~nm}$ (about the beige shea butter), and at $500 \mathrm{~nm}$ (for both butters); they correspond to chlorophyll (A and B) and carorenoïds wavelengths, respectively. The melting of such molecular would justify the great interest of cosmetic and pharmaceutical industries for shea butter and would then constitute an advantage for using the studied shea butters in cosmetics formulations as UV protectors against carcinogenic UV (B and A).

The information delivered by the optimized shea butters near infrared spectra was identical to that of the marked and original shea butters and would confirm and suggest the adoption of the spectra (UV-visible and near infrared) as shea butter specific distinctive characteristics. Hence, any adulteration with other fats and/or alteration would be noticed through the profile. It is nevertheless important to precise a little difference between the beige and the yellow shea butter which consists in a relatively higher intensity of the peak at $450-500 \mathrm{~nm}$ for the yellow (1.5224) shea butter than the other (1.1734). This situation would be relative to the intensity of the color as confirmed by the yellow shea butters high Lovibond colour value in red light (3.9 against 3.4 for the beige one).

In summary, both beige and yellow optimized shea butter would contain the same compounds as hydrocarbon, unsaturated molecular, fatty acids, and molecular protecting against sun rays' damages (allergy and cancer), in probably different amounts.

\section{Biochemical and Nutritive Characteristics of Beige and Yellow Optimized Shea Butters}

Biochemical characteristics also varied from a color to the other, according to the Duncan's test (Table VII). At the whole, these characteristics are very interesting and would confer to both butters a wide potential of utilization when added to the upside physicochemical characteristics. In fact, the important amount of unsaponifiable matter, higher than those of marked shea butters could constitute an interesting economical material for the cosmetics industry.

It is worth noting here that the unsaponifiable fraction would contain the main potential of cosmetic and medicinal virtues. Moreover, the studied shea butters were odourless (moderate odor), registered very weak acid and peroxide indexes, and contained UV-filter compounds, exaltolide (musk fragrance), vitamin (A and $\mathrm{E}$ ) and linoleic acid.

TABLE VII: BIOCHEMICAL AND NUTRITIVE PROPERTIES OF THE OPTIMIZED BEIGE AND YELLOW SHEA BUTTERS

\begin{tabular}{ccc}
\hline Characteristics & Beige shea butter & Yellow shea butter \\
\hline Unsaponifiable $(\%)$ & $17.61 \pm 0.01 \mathrm{a}$ & $17.27 \pm 0.01 \mathrm{~b}$ \\
Vitamin A $(\mu \mathrm{g} / \mathrm{g})$ & $0.065 \pm 0.001 \mathrm{a}$ & $0.032 \pm 0.001 \mathrm{~b}$ \\
Vitamin E $(\mathrm{ppm})$ & $2992.09 \pm 1.90 \mathrm{~b}$ & $3788.44 \pm 1.90 \mathrm{a}$ \\
Carotene $(\mathrm{ppm})$ & $550 \pm 50.00 \mathrm{a}$ & $544 \pm 50.00 \mathrm{a}$ \\
Free Fatty Acids $(\%)$ & $5.39 \pm 0.05 \mathrm{a}$ & $5.23 \pm 0.05 \mathrm{~b}$ \\
SFA $(\%)$ & $48.81 \pm 0.09 \mathrm{~b}$ & $62.72 \pm 0.09 \mathrm{a}$ \\
UFA (\%) & $51.19 \pm 0.19 \mathrm{a}$ & $37.28 \pm 0.19 \mathrm{~b}$ \\
\hline
\end{tabular}

Such characteristics would exalt their exploitation in cosmetic (body cream, soap, fragrances/perfumes, etc.) and pharmaceutical industries like cocoa and jojoba fats, without preliminary treatment like deodorization, neutralization, and synthetic fragrance (essence) involving. 
Concerning the fatty acids composition (Fig. 12), it should underline the high nutritive potential of the optimized shea butters. Indeed, in addition to the vitamins $\mathrm{A}$ and $\mathrm{E}$, and carotene, the chromatographic profile revealed the presence of essential fatty acid (EFA) such as oleic and linoleic acids.

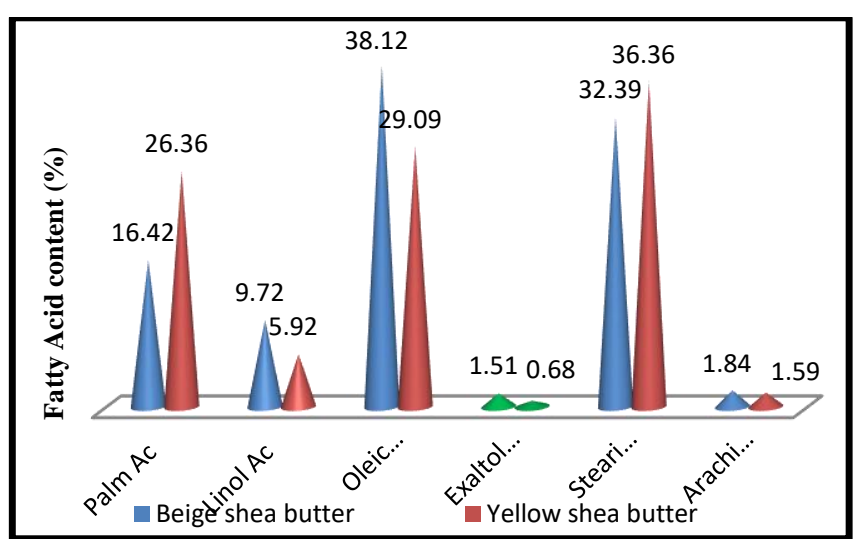

Fig. 12. Optimized shea butters fatty acids component and content.

Their proportions were relatively important, mainly in the beige shea butter and would suggest the possibility of extracting a liquid fraction like "olein de karite" of Burkina Faso. Such faction could be consumed without heating, preserving hence, vitamin ( $\mathrm{A}$ and $\mathrm{E}$ ), carotene and other thermo-sensible molecular from destruction. The solid fraction which will be constituted by stearic and palmitic acids could for it, be involved in margarine and/or in baking pastes to get leafy-pastes as reported by Pesquet [4] about shea butter exploitation in bakery.

About fatty acids, if the difference in content between the beige and the yellow shea butter could be difficultly explained, the higher proportion of UFA $(51.19 \pm 0.19 \%)$ recorded by the beige one was in conformity with Marantz et al [13] report on West Africa shea butters. Nevertheless, the palmitic and linoleic acids proportions were more important, despite of the lack of adulteration supposed for marked shea butters. This situation far from constituting a problem could be taken into account for a best detail in shea butter characterization as function to the country, and in a same country, as function to the trees genetical and agromorphological characters. Carotene content were relatively weak in the yellow shea butter (544 ppm) compared with the beige one $(550 \mathrm{ppm})$; this would confirm the impact of Cochlospermum tinctorium dye in yellow butters coloration [28], [51] and also suppose the implication of other carotenoids (different from carotene) with regard to the Near infrared observation (peaks at $450 \mathrm{~nm}$ ).

In addition to their high physicochemical and biochemical potentialities as cosmetical/pharmaceutical and nutritive fats, the optimized shea butters contained very interesting mineral for both human nutrition as calcium, magnesium, iron, and copper are concerned, and for body /hair care as for zinc, magnesium, and copper [79]. Moreover, no heavy metals (Table VIII) were detected. Some authors like Sanou [17] links shea butters minerals composition to the kernels one, according to the present results, yellow shea butter composition in copper would result from Cochlospermum tinctorium roots. It is essential recalling here that the yellow optimized shea butter was prepared with the decoction of these roots.
TABLE VIII: OPTIMIZED SHEA BUTTERS MINERAL COMPOSITION AND

\begin{tabular}{cccccccccc}
\hline Samples & $\mathrm{Cu}$ & $\mathrm{Fe}$ & $\mathrm{Pb}$ & $\mathrm{Ni}$ & $\mathrm{Zn}$ & $\mathrm{Ca}$ & $\mathrm{Na}$ & $\mathrm{Mg}$ & $\mathrm{K}$ \\
\hline B SB & 0.95 & 0.00 & 0.00 & 0.00 & 0.00 & 212.26 & 84.57 & 0.00 & 45.17 \\
YSB & 7.15 & 1.67 & 0.00 & 0.00 & 1.90 & 238.85 & 136.62 & 12.18 & 36.41 \\
$\mathrm{SK}$ & 3.30 & 30.65 & 0.00 & 0.00 & 9.79 & 2151.80 & 739.58 & 1425.60 & 10488.00 \\
C.t.r & 12.95 & 83.89 & 0.00 & 0.50 & 11.24 & 1649.90 & 696.32 & 1177.95 & 3912.75
\end{tabular}

BSB: Beige shea butter, YSB: Yellow shea butter, SK: Shea kernels, C. t. r: Cochlospermum tinctorium root

\section{Microbiological Characteristics of the Optimized Shea Butters}

The value of zero (0) microorganisms recorded (Table IX), would confirm the deep implication of shea butter conditioning in its microbiological quality. As recall for the upside observations, wrappers bad hygienic quality and the exposure to atmospheric air, dust and exhaust fumes were supposed to induce the contamination by microorganisms and heavy metal of the marked shea butters. Hence, the optimized shea butters might be apt to either exportation or industrial and households' utilizations.

TABLE IX: MiCROBIOLOGICAL CHARACTERISTICS OF THE OPTIMIZED SHEA BUTTERS

\begin{tabular}{cccc}
\hline Identified germs & Standard & $3 \times$ Standard & Shea butter charge \\
\hline Mesophiles bacteria/g & $<1 \times 10^{+4}$ & $<3 \times 10^{+4}$ & 0 \\
Total Coliforms $/ g$ & $<25$ & $<75$ & 0 \\
Yeast and moulds/g & $<10$ & $<30$ & 0 \\
Salmonella $/ \mathrm{g}$ & 0 & 0 & 0 \\
\hline
\end{tabular}

As recall optimized shea butters acid, moisture and peroxide values were very weak, moreover, they were microbiological germs and heavy metal free; this would suggest them apt to exportation and industrial exploitation. In addition, they contained nutritional elements like essential fatty acids (oleic and linoleic acids), minerals (calcium, iron, copper, magnesium, sodium, potassium, and zinc), vitamins (A and E) and carotene, which would dispose them as cheap and accessible nutritive edible fats. They could then be exploited not only in households, but also in food industries, mainly edible oils factories and also in pastries/bakeries because of their high unsaponifiable matter. These latest compounds added to the presence of UV-filter molecules, vitamin E, minerals (zinc, magnesium, and copper) and linoleic acid, would present them as useful raw material for cosmetic and pharmaceutical purposes. However, it should be appropriate to conserve them in hygienic condition in order to preserve such interesting virtues.

\section{CONCLUSION}

Traditional marketed shea butters presented various color (beige or whitish, yellow, and grey), odors (shea characteristic odor and rancid) and textures (compact/hard and fondant). Nevertheless, shea butter consumers mostly prefer beige (whitish), odorless and fondant shea butter; the grey shea butter and rancid one would be considered as bad products.

The raisons of such bad quality would be related not only to the bad conditioning of shea butters on markets, but also to the uncontrolled manufacturing factors as the drying mode and time, kernel quality and roasting time and shea butter post-preparation conditioning (wrappers hygienic quality) The recommended manufacturing conditions would be sun- 
drying for a maximum of one week in order get lowest peroxide compounds, but also to guaranty a high amount of unsaponifiable and also reduce/avoid moulds development on kernels, and then prevent shea butter from rancidity, high amount of peroxide matter and micro-organism toxins. The kernels roasting time might not exceed five (5) minutes for a portion of 500 grams heated under $120-150{ }^{\circ} \mathrm{C}$, so that the color, the odor, the acid/peroxide index would be slighter. Above all, the resulting shea butter might be conserved in clean wrapper in order to avoid germs contamination.

However, these traditional shea butters mainly as the beige and the yellow are concerned, would comport a wide potentiality for industrial exploitation linked to their interesting physicochemical and biochemical characteristics. Nevertheless, their relatively high acid, moisture, and peroxide values, added to their content in microbiological germs and heavy metals might disqualify them from any eventual international trade and industrial exploitation.

When respecting these all condition, the resulted shea butters were not only in conformity with international quality, mineral and microbiological standards for edible fats, but also comported a great and wide potentialities for food and cosmetic/pharmaceutical industries exploitation. Indeed, the specific gravity and viscosity values were specific to edible vegetable fat. Moreover, their essential fatty acid (oleic and linoleic acid) and minerals like calcium, iron, magnesium, and zinc, would profile a benefic exploitation in human nutrition, and then in food industry. The $\mathrm{pH}$ value in conformity with the human body one, the very high unsaponfiable content, mineral such as zinc, the UV-filters compounds, carotene, linoleic acid, vitamin A and E, so did the presence of natural fragrance like exaltolide would enhance their quality of potential fats for cosmetic/pharmaceutical utilizations. Adopting shea butter optimized method would guaranty the trading/exportation/industrial exploitation of this fat which is considered as the main source of money for women in shea producing area, and consequently monetary currency for shea producing countries. Above all, the similitude between the spectra ultra-violet and infrared of the whole studied samples (marked and optimized shea butters) would suggest the spectra to be essential parameters for shea butter traceability; any adulteration and alteration could be easily detected.

\section{ACKNOWLEDGMENTS}

The authors are grateful to the producer of shea butter sector of north west Côte d'Ivoire for their collaboration and technical assistance.

Also, we thank Dr. ZOUE Thierry (Laboratoire de biotechnologie, Agriculture et valorisation des ressources naturelles, Université Félix Houphouet-Boigny, Abidjan, Côte d'Ivoire) and the members of the staff of the laboratory of biotechnology for helpful discussions and advices.

\section{REFERENCES}

[1] K. Schreckenberg, "The contribution of shea butter (Vitellaria paradoxa CF Gaertner) to local livelihoods in Benin," Forest products, livelihoods and conservation. Case studies of non-timber forest product systems, vol. 2, pp. 91-113, 2004.

[2] N. Unies, "Programme des Nations Unies pour le développement (PNUD)," Human Development Report, 2006.

[3] J. D. Hall, H. Aebischer, R. Tomlinson, J. Oselamaning, and K. Hindle, "Vitelaria paradoxa: Monograph School of Agriculture and Forest Sciences Publication 8," Bangor, Wales. University of Wales, 1996.

[4] J. J. Pesquet, "Le Karité. APROMA," Revue Bimestrielle, no. 27-28, pp. $8-13,1992$.

[5] J. Pontillon, "Cocoa, borneo illipe, karité," Oils and fats manuels, Lavoisier. Paris, pp. 206-212, 1996.

[6] H. S. Nahm, "Quality characteristics of West African shea butter (Vitellaria paradoxa) and approaches to extend shelf-life," $\mathrm{PhD}$ Thesis, Rutgers University-Graduate School-New Brunswick, 2011.

[7] A. A. K. Global, "Lipex ${ }^{\circledR}$ Shea butter family," Technical bulletin Aarhus Karlshamn Lipids care. Aarhus Karlshamn. Retrieved from http://www. Integrity ingredients corp. Com/resources/Shea+ Butter+ family. pdf, 2012.

[8] Union Economique et Monétaire Ouest Africaine [UEMOA], "Spécification du beurre de karité non raffiné," PN UEMOA ICS-67, p. 13, 2011.

[9] C. Carette, M. Malotaux, M. van Leeuwen, and M. Tolkamp, "Sheanut and butter in Ghana," Opportunities and constraints for local processing. University of Wageningen, 2009.

[10] R. M. Mégnanou and K. J. Diopoh, "Caracterisation Sensorielle, Physico-Chimique Et Microbiologique Du Beurre De Karite, Vitellaria paradoxa Des Marches De Cote D\$ Ibackslash\$'Ivoire," Agronomie Africaine, vol. 20, no. 2, pp. 221-231, 2008.

[11] M. Elias and J. Carney, "The female commodity chain of shea butter: Burkinabe producers, western green consumers and fair trade," Cahiers de Geographie du Quebec, vol. 48, no. 133, pp. 71-88, 2004.

[12] C. Kapseu, H. M. Womeni, R. Ndjouenkeu, M. F. Tchouanguep, and M. Parmentier, "Influence des méthodes de traitement des amandes sur la qualité du beurre de karité," Proc. Biol. Alim, vol. 3, pp. 1-18, 2005.

[13] S. Maranz, Z. Wiesman, J. Bisgaard, and G. Bianchi, "Germplasm resources of Vitellaria paradoxa based on variations in fat composition across the species distribution range," Agroforestry systems, vol. 60, no. 1, pp. 71-76, 2004.

14] D. Soro, "Déparasitage par émondage et production en fruits du parc naturel à karité de Tengrela dans le Nord de la Côte d'Ivoire," Mémoire de DEA, Laboratoire de Botanique, UFR Biosciences, Université de Cocody, Côte d'Ivoire, 1999.

[15] D. Nafan, "Caractérisation agro morphologique de la population spontanée de karité (Vitellaria paradoxa CF Gaertn) du parc agroforestier à karité de Tengrela, en Côte d'Ivoire," Mémoire de DEA, Biotechnologie et Amélioration de la Production Végétale, Université d'Abidjan-Cocody,(Côte d'Ivoire), 2000.

[16] G. J. B. Gnonlonfin, L. Fanou, P. Fandohan, R. Adéoti, O. Coulibaly, K. Hell, B. Bohou Vidégnon, A. L. Ahoussi, P. Houssou, L. Koumassa, G. A. Mensah. "Amelioration et controle de qualité des produits agricoles alimentaires au Benin ", Rapport technique final de projet. Bibliothèque Nationale du Benin, 79, 2011

[17] H. Sanou, "Espèce ligneuse du Mali: Vitellaria paradoxa (Sapotaceae)," Espèces ligneuses alimentaires. IPGRI Nairobi (Kenya), 2002

[18] J. M. Ames, "Applications of the Maillard reaction in the food industry," Food Chemistry, vol. 62, no. 4, pp. 431-439, 1998.

[19] D. Machiels and L. Istasse, "La réaction de Maillard: importance et applications en chimie des aliments," Ann. Méd. Vét, vol. 146, pp. 34352, 2002.

[20] L. Maliga, "Shea butter-Africa's Golden Gift," http://www.articlecity.com, 2008.

[21] M. Tasan and M. Demirci, "Total and individual tocopherol contents of sunflower oil at different steps of refining," European Food Research and Technology, vol. 220, no. 3, pp. 251-254, 2005.

[22] H. Moharram, J. Ray, S. Ozbas, H. Juliani, and J. Simon, "Shea butter: Chemistry, quality, and new market potentials," 2006

[23] V. Van Hoed, G. Depaemelaere, J. V. Ayala, et al., "Influence of chemical refining on the major and minor components of rice brain oil," Journal of the American Oil Chemists' Society, vol. 83, no. 4, pp. 315$321,2006$.

[24] R. M, Mégnanou R-M, “Contribution à l'étude du beurre de karité produit en Côte d'Ivoire et optimisation qualitative de sa fabrication artisanale", Thèse Unique de Doctorat, Université de Cocody, Abidjan (Côte d'Ivoire), 2008. 
[25] R. M. Mégnanou and S. Niamké, "Contribution to the constitution of shea butter sensorial standard based on Ivoirian consumers criteria," International Journal of research in Biosciences, vol. 2, no. 1, pp. 1321, 2013.

[26] P. N. Lovett, The Shea Butter Value Chain: Production, Transformation and Marketing in West Africa. West African Trade Hub Technical Report No. 2. 2004.

[27] C. K. Agyente-Badu, "The effect of Cochlospermum planchonii root dye/extract on the shelf-life of shea butter during storage," $\mathrm{PhD}$ Thesis, 2010.

[28] A. Fyo, "Solar drying of shea nuts". Cocoa Research Institute of Ghana. Ann. Rep. 1988/89. pp.1-121, 1991.

[29] F. Omujal, "Post Harvest Handling Practices and Physico-Chemical Characteristics of Shea (Vitellariaparadoxa) Fruit in Uganda," A Dissertation for the Award of Master of Science in Chemistry of Makerere University: Uganda, 2009.

[30] J. B. L. Okullo, F. Omujal, J. G. Agea, et al., "Physico-chemical characteristics of Shea butter (Vitellaria paradoxa CF Gaertn.) oil from the Shea district of Uganda," African Journal of Food, Agriculture, Nutrition and Development, vol. 10, no. 1, 2010.

[31] R. M. Mégnanou, E. E. Akpa, K. K. A. Sevérin, and S. L. Niamké, "Definition of optimal processing conditions for proposing shea butter sensorial standard via Ivorian consumers' criteria.," International Journal of Plant, Animal and Environmental Sciences, vol. 3, no. 1, pp. 7-14, 2013.

[32] P. C. Aculey, S. T. Lowor, W. O. Kumi, and M. K. Assuah, "The effect of traditional primary processing of the shea fruit on the kernel butter yield and quality," Am. J. Food Technol, vol. 7, pp. 73-81, 2012.

[33] J. F. Cruz, F. Troude, D. Griffon, and J. P. Hebert, "Conservation des grains en régions chaudes-Techniques rurales en Afrique," Ministère de la Coopération et du Développement (2. ed), F. Paillart Abbeville, Paris (France), pp. 1-545, 1988.

[34] A. Dieffenbacher, P. Buxtorf, R. Derungs, R. Friedli, and K. Zürcher, "Graisses comestibles, huiles comestibles et graisses émulsionnées," Graisses comestibles, huiles comestibles et graisses émulsionnées, Société des chimistes analystes suisses, Berne, pp. 1-249, 2000.

[35] A. M. Mohagir, R. Kamga, C. Kapseu, and C. F. Abi, "Optimization of some pre-treatments involved in the press extraction of shea (Vitellaria paradoxa Gaertner F.) butter.," Asian journal of applied sciences, vol. 2, no. 4, pp. 372-384, 2009.

[36] A. Pfohl-Leszkowicz and M. Castegnaro, "Rôle des mycotoxines dans le développement de certains cancers," Toxines et recherche biomédicales, collection SFET, Goudey-Pirrière F, Bon Cassian, Puiseux-Dao S, Sauviat MP (eds) Elsevier, New York, pp. 142-152, 2002.

[37] C. Broutin, J. D. Hounhouigan, and V. Anihouvi, "Normes de qualité pour les produits agroalimentaires en Afrique de l'Ouest," 2009.

[38] K. P. Ntema, "Produits forestiers alimentaires: utilisation, transformation, conservation et demande du marché," éditeurs. 2002. Réseau "Espèces Ligneuses Alimentaires ». Compte rendu de la première réunion du Réseau tenue 11-13 décembre 2000 au CNSF Ouagadougou, Burkina Faso. Institut International des Ressources Phytogénétiques, vol. 30677, p. 196, 2002.

[39] H. M. Womeni, "Identification et analyse des opérations critiques de préparation des fruits, graines et amandes de karité (Butyrospermum parkii (G. Don) Kotschy): étude de leur influence sur la qualité du beurre," PhD Thesis, Thèse de Doctorat/PhD en technologie alimentaire, ENSAI, Université de ..., 2004.

[40] D. Louppe, "Le karité en Côte d'Ivoire," 1994.

[41] H. M. Womeni, R. Ndjouenkeu, C. Kapseu, et al., "Application du procédé séchage-friture aux amandes de karité: influence sur la composition en matières insaponifiables du beurre," Oléagineux, Corps gras, Lipides, vol. 14, no. 6, pp. 366-370, 2007.

[42] M. I. West, "The Shea Butter Value Chain," 2004

[43] F. A. Oluwole, N. A. Aviara, and M. A. Haque, "Effect of moisture content and impact energy on the crackability of sheanut," Agricultural Engineering International: CIGR Journal, 2007.

[44] E. Boutrif, "FAO programmes for prevention, regulation, and control of mycotoxins in food," Natural toxins, vol. 3, no. 4, pp. 322-326, 1995.

[45] F. J. Menvielle-Bourg, "Plantes et vieillissement, données actuelles," Phytothérapie, vol. 3, no. 2, pp. 57-71, 2005.

[46] S. J. Risch, C. T. Ho, "Interactions arômes-emballages : rétention d'arômes par des films et des enrobages, " JAgricultFood Chem 48: 1776-1783, 2000

[47] A. Pfohl-Leszkowicz, "Ecologie des moisissures et des mycotoxines : situation en France," Cahiers de nutrition et de diététique, vol. 35, no. 6, pp. 379-388, 2000.
[48] J.-P. Jouany, D. P. Morgavi, and H. Boudra, "Le risque mycotoxique dans la chaîne alimentaire en France," Cahiers de Nutrition et de Diététique, vol. 41, no. 3, pp. 151-158, 2006.

[49] P. Galtier, N. Loiseau, I. Oswald, and O. Puel, "Toxicologie des mycotoxines: dangers et risques en alimentation humaine et animale,' Bulletin de l'Académie vétérinaire de France, p. 5, Jan. 2006.

[50] L. W. Whitlow, W. M. Hagler Jr, and B. A. Hopkins, "Mycotoxin occurrence in farmer submitted samples of North Carolina feedstuffs: 1989-1997," J. Dairy Sci, vol. 81, no. Suppl 1, p. 1189, 1998.

[51] R.-M. Megnanou, S. Niamke, and J. Diopoh, "Physicochemical and microbiological characteristics of optimized and traditional shea butters from Cte dIvoire," African Journal of Biochemistry Research, vol. 1, no. 4, pp. 041-047, 2007.

[52] G. Kajimoto, K. Horikawa, Y. Araki, T. Izumi, and T. Sato, "Etude de la normalisation d'essais de stabilité des graisses. III. Essais de stabilité des graisses à l'oxydation thermique,"Yukagaku, vol. 35, no. 9, pp. 742-746, 1986.

[53] T. P. van Boeckel, J. D. Hounhouigan, and R. Nout, Les aliments. transformation, conservation et qualité. CTA, 2003.

[54] D. V. Adegunloye, O. O. Agarry, T. T. Adebolu, and F. C. Adetuyi, "Effect of leaf-packaging on the microbiological assessment of some food items," African journal of Biotechnology, vol. 5, no. 5, pp. 445 447, 2006.

[55] A. B. Ojekale, S. C. O. Makinde, and O. Osileye, "Phytochemistry and anti-microbial evaluation of Thaumatococcus danielli, Benn. (Benth.) leaves," 2007.

[56] R.-M. Megnanou, L. T. Zoue, and S. Niamke, "Marketed and original shea butters of Côte d'Ivoire: physicochemical and biochemical characterization and evaluation of the potential utilizations," Sustainable Agriculture Research, vol. 3, no. 526-2016-37786, 2014.

[57] R.-M. Mégnanou and S. Niamké, "Effect of nut treatments on shea butter physicochemical criteria and wrapper hygienic quality influence on microbiological properties," Journal of Food Research, vol. 2, no 5, pp. 66-76, 2013.

[58] C. Alimentarius, "Fats and Vegetable oils," FAO/WHO, Geneva, p 160, 1993.

[59] J. B. Rosell, "Purity criteria in edible oils and fats," Lipid/Fett, vol. 93 no. S4, pp. 526-531, 1991

[60] A. Lefur and J.-P. Arnaud, "Les lipides polaires: actifs et vecteurs cosmétiques," Oléagineux, Corps gras, Lipides, vol. 11, no. 6, pp. 436439, 2004.

[61] V. Dubois, S. Breton, M. Linder, J. Fanni, and M. Parmentier, "Fatty acid profiles of 80 vegetable oils with regard to their nutritional potential," European Journal of Lipid Science and Technology, vol. 109, no. 7, pp. 710-732, 2007.

[62] J. M. Nzikou, M. Mvoula-Tsieri, L. Matos, E. Matouba, A. C. Ngakegni-Limbili, M. Linder et al. "Solanum nigrum L. seeds as an alternative source of edible lipids and nutriment in Congo Brazzaville,' Journal of Applied Sciences, vol. 7, no. 8, pp. 1107-1115, 2007.

[63] M. K. Yadav, C. D. Chudasama, and R. V. Jasra, "Isomerisation of $\alpha$ pinene using modified montmorillonite clays," Journal of Molecular Catalysis A: Chemical, vol. 216, no. 1, pp. 51-59, 2004

[64] S. Besbes, C. Blecker, C. Deroanne, G. Lognay, N. E. Drira, H. Attia "Quality characteristics and oxidative stability of date seed oil during storage," Food science and technology international, vol. 10, no. 5, pp. 333-338, 2004.

[65] E. Psomiadou and M. Tsimidou, "Pigments in Greek virgin olive oils: occurrence and levels," Journal of the Science of Food and Agriculture vol. 81, no. 7, pp. 640-647, 2001.

[66] K.-S. Kim, S.-H. Park, M.-G. Choung, and Y.-S. Jang, "Use of nearinfrared spectroscopy for estimating fatty acid composition in intact seeds of rapeseed," Journal of Crop Science and Biotechnology, vol 10 , no. 1 , pp. 13-18, 2007.

[67] Y. C. Man and M. H. Moh, "Determination of free fatty acids in palm oil by near-infrared reflectance spectroscopy," Journal of the American Oil Chemists' Society, vol. 75, no. 5, pp. 557-562, 1998.

[68] A. Karleskind, "Manuel des corps gras. Technique et Documentation,' Lavoisier, Paris, pp. 1-1580, 1992.

[69] F. D. Gunstone, "Food applications of lipids.," Food lipids: Chemistry, nutrition, and biotechnology, no. Ed. 2, pp. 729-750, 2002.

[70] C. Alais and G. Linden, "Abrégé de biochimie alimentaire. 4éme Edition Masson," Paris, (119-123), 1997.

[71] J. J. Salas, M. A. Bootello, E. Martínez-Force, and R. Garcés, "Tropical vegetable fats and butters: properties and new alternatives," Oléagineux, Corps gras, Lipides, vol. 16, no. 4-5-6, pp. 254-258, 2009.

[72] N. A. Kandji, "Etude de la composition chimique et de la qualité des huiles végétales artisanales consommées au Sénégal," Thèse de Doctorat, Université Cheick Anta Diop, Dakar, 2001. 
[73] M. F. Ramadan and J.-T. Mörsel, "Oxidative stability of black cumin (Nigella sativa L.), coriander (Coriandrum sativum L.) and niger (Guizotia abyssinica Cass.) crude seed oils upon stripping," European Journal of Lipid Science and Technology, vol. 106, no. 1, pp. 35-43, 2004.

[74] T. Aburjai and F. M. Natsheh, "Plants used in cosmetics," Phytotherapy Research: An International Journal Devoted to Pharmacological and Toxicological Evaluation of Natural Product Derivatives, vol. 17, no. 9, pp. 987-1000, 2003.

[75] N. Guggenbühl, "Exposé du Symposium 'les oligo-éléments dans l'alimentation en Belgique: données récentes.," Institut Danone, Bruxelle, vol. 18, 2003.

[76] M. M. Diaw, “Contribution à l'étude de l'effet hépato-protecteur du Cochlospermum tinctorium a. Rich. (Cochlospermacees),". Thèse d'État, Faculté de Médecine et de Pharmacie de Dakar, 1982.

[77] C. B. Ndangui, A. Kimbonguila, J. M. Nzikou, L. Matos, N. P. G. Pambou-Tobi, A. A. Abena et al., "Nutritive composition and properties physico-chemical of gumbo (Abelmoschus esculentus L.) seed and oil," Research Journal of Environmental and Earth Sciences, vol. 2, no. 1, pp. 49-54, 2010

[78] P. C. M. Jansen PCM, "Cochlospermum tinctorium Perr. ex A.Rich," In PCM, Jansen, D. Cardon (Eds.). Ressources végétales de l'Afrique Tropicale 3: Dyes and tannins/Colorants et tannins. PROTA Network Office Europe, Wageningen University, P.O. Box 341, 6700 AH Wageningen, Netherland, 2005.

[79] L. Guéguen, "Apports nutritionnels conseillés pour la population française," Paris: TEC \& DOC, Lavoisier (Paris), 2001. 